\title{
DEVELOPING ENGLISH READING AND WRITING MATERIALS FOR AUTOMOTIVE ENGINEERING PROGRAM IN VOCATIONAL HIGH SCHOOL
}

\author{
Endang Lestari ${ }^{1 *}$, Joko Priyana ${ }^{1}$ \\ ${ }^{1}$ Universitas Negeri Yogyakarta \\ Jl. Colombo No. 1, Karangmalang, Depok, Sleman, Yogyakarta 55281, Indonesia
}

\begin{abstract}
The aims of this study are: (1) to identify the needs of grade 11 students of the Automotive Engineering Study Program in learning reading and writing, and (2) to develop appropriate English reading and writing learning materials. This is research and development that employed Jolly and Bolitho's model with some adaptation. The development procedure consists of conducting needs analysis, designing the syllabus, developing learning materials, expert judgment, conducting field testing, and materials evaluation. The research subject was 64 grade XI students of Light Vehicle Engineering or Teknik Kendaraan Ringan (TKR) at Vocational High School (VHS) AX. The needs analysis data indicate that, in learning reading, the students want to learn simple instructions and vocabulary items relevant to the automotive field. They also want to learn to write letters and create simple reports that are relevant to the automotive field. Regarding the theoretical validation, the appropriateness of learning materials is categorized as "very good" according to the expert with a mean score of 3.48 (in the interval $3.28 \leq x \leq 4$ ). According to the students, the appropriateness of the learning materials is categorized as "very good" with a score of 3.54 (in the interval $3.28 \leq x \leq 4)$. In general, the developed learning materials are appropriate for grade 11 students of the Automotive Engineering Study Program of VHS AX.
\end{abstract}

Keywords: automotive engineering, materials development, reading, writing

How to cite: Lestari, E., \& Priyana, J. (2020). Developing English reading and writing materials for Automotive Engineering program in vocational high school. Jurnal Pendidikan Vokasi, 10(2), 167-176. doi:https://doi.org/10.21831/jpv.v10i2.27965

*Corresponding Author: $\quad$ Endang Lestari @ nd9_12taryamaze@yahoo.co.id

- Department of English Education, Graduate School, Universitas Negeri Yogyakarta Jl. Colombo No. 1, Karangmalang, Depok, Sleman, Yogyakarta 55281, Indonesia 


\section{INTRODUCTION}

Vocational education belongs to the domain of formal education, which is one of three recognized streams of education in Indonesia alongside non-formal and informal education. Within the vocational track, the vocational school offers secular academic subject and subject that focuses on technical skill (Kadir et al., 2016). Vocational Education has a link with industries. The endusers of the skills acquired by vocational school graduates are employers. The fundamental in ensuring that new graduates are equipped with the employment relevant skills is a close partnership between the industries and vocational education institutions. The Indonesian Ministry of Education and Culture pioneered the "link and match" policy for Vocational High School (VHS) and tertiary vocational education to promote an industry-based vocational education model.

Kadir et al. (2016) stated that curriculum development in VHS and the tertiary vocational institution must adhere to the national competency standards at work meant for the courses offered to bridge the gap between what is learned in schools and the actual standards demanded by the industries. According to Komarudin et al. (2017), there are several problems that are faced by Indonesian VHS: (1) the control of vocational competency of students is still categorized less, as much as $20 \%$ of Automotive students did not pass in the test, (2) in some researches, the mastery of vocational competence is influenced by many factors: method, learning model, (3) facilities and infrastructure, and (4) self-efficacy should be considered to improve achievement and vocational. Moreover, Haq et al. (2019) mentioned that in the dimensions of being and having self-efficacy as the aspect of being and student-teacher relation. In line with this, Soeprijanto et al. (2019) classified the problems into man, machine, method, material, and money.

Durmuş and Dağli (2017) stated that vocational schools' curriculums need to be re-audited so they can keep pace with rapidly changing industry conditions in recent years. The world automobile industry is expanding fastly, so it has an important role in the Indonesian economy. The branch offices of a foreign automobile company in Indonesia are broader. The condition pushes the graduates of vocational high school to be directed to the workplace, especially in the Automotive sector. There is a potential to use English in daily communication in the context of the Automobile industry. Since Indonesian VHS is applying the 2013-curriculum, the government lacks English learning material that is specific designed for the Automotive field. In terms of learning materials in the 2013-curriculum, they are integrated into two or more skills. An integrated study is, one in which, students broadly explore knowledge in various subjects related to their certain environment aspects.

Brown (2001) believes that when the language skills are integrated, students have a chance to diversify their efforts in meaningful tasks. Reading is one of the respective skills that must be mastered by students, and also writing is the continuity of reading for producing something, namely, productive skills have to be drilled often. In line with this, Richards and Renandya (2002, p. 273) emphasize that good reading texts can provide good writing models and provide chances for stimulating discussion. In the reading class, students are asked to read the text related to their needs in the Automotive Engineering field, while in writing class, they are asked to be ready in writing some texts related to their jobs. Since reading is the continuity of writing, the students can read texts and create similar text with different topics in writing class through reading class.

At Vocational High School $A X$, English for Automotive Engineering is taught by two different teachers for two classes: TKR A and TKR B. The first teacher teaches the TKR A class, the other one teaches the TKR $B$ class following the English course syllabus. Vocational High School (VHS) in Indonesia is run under the umbrella of English for Specific Purposes (ESP). The objectives that the students will go to work on are related to their skills. The historical schools' data support that most of the graduates of Vocational High School $A X$ are offered to work at an automobile company or workshop, such as Astra, Mitshubishi, Nasmoco, Suzuki, and so on. Hence, students need English learning materials containing input texts related to their field, Automotive Engineering.

Since some of the textbooks used by the English teacher and the students are not yet appropriate in Vocational High School $A X$, improvement has to be done in the near future. Currently, the main textbook used at the school is "Bahasa Inggris," and students' worksheet (LKS) is "Master Bahasa Inggris", both of them focus on General English. Despite the textbook is in line with the required curriculum standard, there is no specific aspect related to Automotive Engineering. 
The fact shows a contrast with the concept of ESP. Hutchinson and Waters (1987) accentuate that what distinguishes English for Specific Purposes (ESP) from General English is the awareness for the former towards the students' needs. The specific inputs in learning English in terms of input texts and the technical terms on Automotive Engineering are needed. The learning materials have been developed to be the guidance for the English teacher in order to consider the learning needs. In line with this, Jaleniauskiene et al. (2019) suggest that educators need to develop and integrate more professional guidance to support the development of students' skills.

Furthermore, in his research, Yang (2019) also got the finding that many students still need the teachers' guidance in studying English as a foreign culture may be new to them. Thus, this research aims to develop English reading and writing learning materials for grade 11 students of the Automotive Engineering study program of Vocational High School AX.

\section{RESEARCH METHOD}

In developing the learning materials, the researchers adopted the development model proposed by Jolly and Bolitho (Lestari \& Priyana, 2019) with some adaptations. According to their model of development, there are some steps to develop the learning materials, shown in Figure 1.



Figure 1. Jolly and Bolitho Model of Development (1998) (Lestari \& Priyana, 2019)

However, to make the development steps more feasible, some adaptation of the steps were conducted based on the real condition. The researchers combined the second, third, and fourth steps of Jolly and Bolithos' model of development into one step, namely designing the syllabus. The sequence of the development processes can be seen in Figure 2.

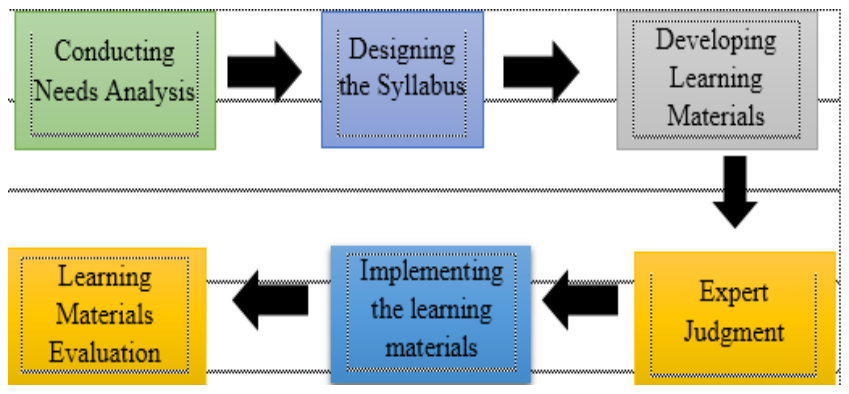

Figure 2. The Model of Development 
At the beginning of the development, the researchers gathered the data by identifying the students' needs. The questionnaire was used to collect the data. Moreover, the researchers conducted an interview with English teachers related to the English teaching-learning process and the vice head master for curriculum concerning the curriculum in Vocational High School AX. After that, the researchers analyzed the result of the needs analysis and the interview result as guidelines to design the syllabus and develop the learning materials. Developing the reading and writing learning materials based on the syllabus was conducted in this stage.

The first draft was developed based on the syllabus. The researchers did an expert judgment step. To deal with the validity of the learning materials, the researcher distributed a questionnaire to the expert of the learning materials. The questionnaire covered some items related to identifying the appropriateness of content, presentation, language, and layout. The first product of the learning materials was revised based on the comment, suggestions, feedback, and judgments from the learning material expert. The data from the first product were used to develop the second draft of learning materials. The following step was the implementation of the learning materials. In this step, the students were asked to use the textbook entitled "AUTOCAR English" as supplementary reading and writing learning materials.

The implementations were divided into two stages, namely small group implementation and field implementation. In small group implementations, there were eight students as the sample of the implementation. To gain qualitative data, the researchers did interviews with the students and the English teacher. Furthermore, field implementation was conducted. The researchers distributed a questionnaire to the students after the implementation to gain the data related to the learning materials' appropriateness. In this stage, the learning materials were evaluated whether the materials met the objectives. The evaluation before the implementation was conducted by revising the product based on the suggestion, comments, and feedback from the expert. The evaluation after the product had been implemented regarding the comment and feedback from the students.

\section{RESULTS AND DISCUSSION}

The research findings are the need analysis data and the appropriateness of the learning materials to the needs. The findings are described in the following steps of development. The first step of the development was needs analysis. It was aimed to find out the target needs and learning needs. As a learning material for ESP learners, the developed learning materials should be based on needs analysis since this is the difference between ESP from others (Hutchinson \& Waters, 1987). In the needs analysis step, the data were collected through observing the existing textbook and documents, conducting an interview, and distributing a questionnaire. The questionnaires were developed by adopting the principle of needs analysis, which is proposed by Hutchinson and Waters (1987). It covers target needs and learning needs. In terms of target needs, the questionnaire items were divided into four components: necessities, lacks, wants, and goals. The results of target needs will be concerned as the basis for developing the learning materials.

Thus, they need activities that can facilitate them to collaborate with their classmates, possibly through discovery learning activities. This is in line with Sutman et al. (2008) that teamwork is considered as an essential development of students' discovery during instruction. It is often advisable that the class can be grouped into teams before a lesson begins.

In terms of learning needs, it covers some key aspects: input, activities (procedure), setting, learners' role, and teachers' role. Those components are also considered as the component of the task on the chapters developed. The first aspect of learning needs is input. Nunan (2004) describes input as the source of learning. In this research, the input of the learning was taken from reliable sources. Based on the result of needs analysis, the students' input texts are those related to Automotive Engineering. Since the developed materials are reading and writing, the given input texts were in the form of written texts. Among the graduate of technical colleges had a lack of reading and writing proficiency (Goyol \& Sunday, 2020). It can be said if there was need an improvement in the skills.

The next aspect is the setting. Nunan (2004) defines the term "setting" as the way to carry out the works. Based on the needs analysis, the students preferred working in small groups consist- 
ing of three or four students. Therefore, to meet the needs, the tasks are mostly designed to be done in a small group consisting of three or four students.

The fourth aspect is the role. By concerning to needs analysis result, the students mostly preferred to use their creativity in doing the task in terms of learner's role. They also preferred to participate in the classroom discussion actively. In line with this, one of the strengths of discovery learning is stimulating the learners to be active learners (National Agency for Education Standard, 2016). Therefore, most of the tasks emphasize the process of discussion, especially in a small group that consists of three or four students. In terms of teacher's role, the students preferred that the teacher creates a good atmosphere to get the students' involvement in the classroom and motivate them to do the task.

After analyzing the needs, the next step is designing the syllabus. Before the materials are developed, the syllabus was made as a guideline to develop the learning materials. The syllabus covers basic competences of Vocational High School such as the name of the school, program of expertise, class and semester, number of the chapter, chapter's title, topics, text type, learning indicators, input, language focus (grammar and vocabulary), and the description of learning activities. The reading and writing learning materials were develop based on the syllabus. Designing the learning material using the syllabus developed will increase the competencies of the participants at workplaces because the syllabus is designed based on the needs (Guerid \& Mami, 2017).

The development of the learning materials considered the theories presented in the literature review. The researchers referred to Richards (2015) in designing the reading activities embedded in the task for grammar knowledge and vocabulary knowledge. The goals were decided, and then the reading texts were selected. There were six text types of a formal invitation: personal letter, manual, factual report, analytical exposition, and biography text; while for deciding the types of reading classroom performances, the researcher referred to Brown (2001), who classified silent reading into two categories: intensive and extensive readings. In terms of classroom writing performances, the researcher referred to Brown (2001), which mentioned some kinds of writing performances such as imitative, intensive, self-display, and real writing. Since the learning materials are integrated between reading and writing tasks, the researchers adopted the types of integration proposed by Baturay and Akar (2007). They stated that using an integrated skills approach enables the student to develop their ability to use two or more of the four skills within the real contexts and in a communicative framework.

Besides, micro and macro skills of reading and writing proposed by Brown (2004) were also considered. The realization of micro-skills of reading was conducted by providing activities that facilitated students to recognize the core of words, interpret word order patterns and their significance, and also recognize grammatical word classes, systems, patterns, rules, and elliptical forms through collaborative learning activities in small group discussion. In order to support the student in realizing the macro skills of reading: to recognize the communicative function of written text, according to form and purpose; to infer context that is not explicit by using background knowledge; and to describe events, ideas, new information, and generalization through an individual task, pair work, and small group work.

The researchers designed some reading tasks to facilitate students' learning reading like skimming tasks, ordering tasks, open-ended reading comprehension questions, cloze procedure, contextualized grammar editing tasks, editing tasks, and selected-response fill in vocabulary, and matching tasks. Regarding to micro and macro skills of writing proposed by Brown (2004), the researchers also facilitated the students to produce writing at an efficient rate of speed to suit purpose; to use cohesive devices in written discourse; and to use acceptable grammatical system, patterns, and rules through some writing tasks to implement micro skills of writing. In terms of macro skills of writing, the researcher highlighted some macro skills: appropriately accomplish the communicative functions of written texts according to the form and purpose; develop and use writing strategies using paraphrases and synonyms, soliciting peer instructor feedback for revising and editing; convey links and connection such as give new information and generalization. One of the solution for writing teachers by developing supplementary writing materials if the available materials are not appropriate with the students' ability (Nurhajati, 2018). 
The researchers designed some writing tasks to facilitate the students in learning writing, such as picture-cued task, grammatical transformation task, ordering task, and paraphrasing task. Reading is integrated into writing task since it was in line with Richards and Renandya (2002), who emphasize that good reading texts can provide a good model of writing and provide the chance of stimulating discussion.

Jaleniauskiene et al. (2019) mentioned some typical skills that must be promoted in tasks: information, communication technology literacy, creativity, innovation, critical thinking, and problem-solving. One of the government's teaching methods in 2013-curriculum that directs the students to be problem solvers is discovery learning.

In this development stage, the way to incorporating discovery learning activities in the classroom were through discovery learning steps based on a chapter. There were six chapters developed. Regarding the standard of contents for VHS (Regulation of Minister of National Education No. 22 of 2006), the learning activities need to be contextualized with the curriculum and the student's needs. Since Vocational High School $A X$ adopted C-13, the researchers highlighted an approach proposed by the Law of Republic of Indonesia No. 20 of 2003 as the basis to develop the learning materials, Discovery learning. The learning materials also developed in line with an automotive field by entering some Automotive Engineering topics that consist of engine, transmission, carjacking, piston, compressor, and the like. In line with this, Hui (2016) mentioned that English for Automobile is a branch of ESP that is composed of different units, parts, and systems: engine, transmission, steering, mechanism, chassis, suspension, or the electrical system. Paltridge and Starfield (2012) state that ESP specialists accept the responsibility for finding out what their learners will likely need to be, especially in reading, writing, speaking, which are comprehend for listeners to achieve their goals. Since in achieving their goals, the students are not presented directly to the properties, but they are to be discovered through experimentation and interpretation (Gijlers \& de Jong, 2005). The students will have an opportunity to enrich personal knowledge on a particular thematic area or topic, developing a more comprehensive opinion and being ready for such an inclass discussion or a student presentation session.

In designing the learning materials, the researchers adopted discovery learning steps proposed by the Law of Republic of Indonesia No. 20 of 2003, where there are six steps: stimulation, problem statement, data collecting, data processing, verification, and generalization. Before the simulation step, the researcher took warm-up activities. Sutman et al. (2008) mentioned some criteria of discovery skill for grade 9-12 students such as, students are asked to be able to use the technology for improving investigation and communications since in the learning materials developed, the researcher added some tasks that asked the students to use the internet to find supporting data.

Regarding the lesson plan in the 2013-curriculum for one semester, the developed reading and writing learning materials are divided into six chapters. The result of need analysis shows that the students choose to design the chapter consisting of 15-19 tasks. In chapter 1, the students are directed to study formal invitations. In chapter 2 , the students will study personal letters. In chapter 3 , the students will study manual texts. Moreover, in chapter 4, the students can study factual report texts. In chapter 5, the students are directed to study analytical exposition texts. In chapter 6, the students can study biography texts. Each chapter has (a) chapter title and learning objectives; (b) warm-up activities; (c) the main activities designed based on discovery learning activities since discovery learning is one of the teaching method that proposed by the government in line with 2013curriculum. It consists of stimulation, problem statement, data collecting, data processing, verification, generalization, (d) word list; and (e) self-reflection. Remembering that nowadays, some students are lack collaboration skills, so the ESP teachers should involve language learners in collaborative learning environments more frequently (Jaleniauskiene et al., 2019).

After the learning materials were ready, the next step was expert judgment. It was aimed at finding out the feasibility of reading and writing learning materials based on micro-skills opinion. The learning materials were evaluated by the learning material expert in the English materials developed field. There were four aspects to be observed consist of the feasibility of content, presentation, language, and layout design. The evaluation process was done by distributing the four-point Likert-scale questionnaire. The questionnaire was developed based on the Instrument Penilaian Buku Bahasa Inggris SMK since the solutions of the learning materials were appropriate with stu- 
dent's needs of Automotive Engineering Study Program due to soforevisions. The comments, suggestions, and feedback from experts were used to complete the second draft and make the final draft more appropriate. Since the learning material was categorized as "Very Good," some revisions had been made based on the expert judgment results, as presented in Figure 3. Some points should be revised.

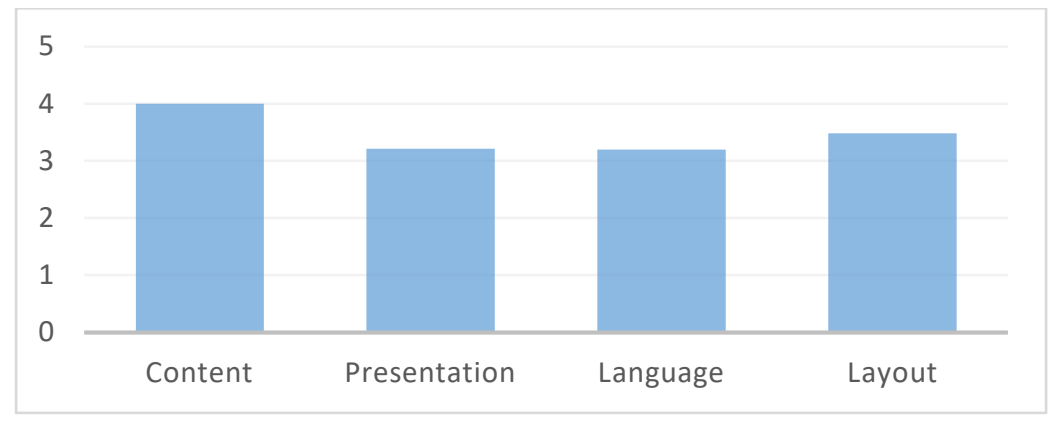

Figure 3. Expert Judgments' Result

Moreover, the expert also gave some suggestions through an interview. In general, the expert considered that the learning materials were appropriate and ready to be implemented in the school by revising some and considering the result of the expert's comments and suggestions. The comment, suggestions, and feedback from the expert were used to complete the second draft and make the product more appropriate.

After being revised, the reading and writing learning materials were implemented. There were two implementations of small group implementation and field implementation. First, the small group implementation was conducted to re-check the contents of the textbook. The researcher did an interview to identify the students' opinions related to the learning materials. There were eight students taken from two classes, namely TKR $A$ and TKR B. The result of the interview was good enough. The students gave positive responses related to the learning materials. In short, the learning materials meet with students' needs of Automotive Engineering.

After the small implementation was conducted, the learning materials were implemented in the field implementation. The field implementation subject was grade 11 students of Automotive Engineering Study Program of Vocational High School AX, Indonesia by total students were 64. Because of some limitations, the researcher only implemented three chapters, namely Chapter 1 , Chapter 3, and Chapter 6. The chapters are considered by the students randomly based on their interests. After the field implementation was finished, the researchers distributed the questionnaire, which was handed to the students. Four aspects must be evaluated, namely the appropriateness of content, presentation, language, and layout design, as presented in Figure 4.

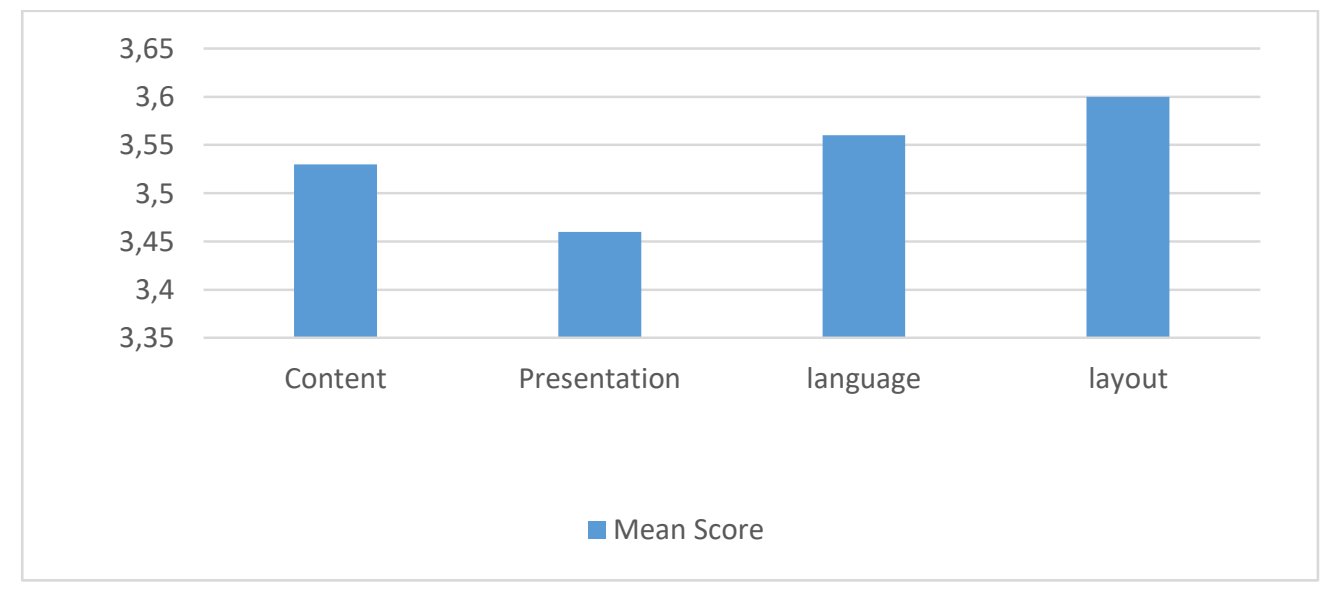

Figure 4. The Appropriateness Based on Students' Argument 
Furthermore, all aspects were categorized as "Very Good." There was no specific revision based on the students' comments and suggestion, since the result of the implementation needs other sources and technology such as the internet to help the students find the data related to the topics being discussed. The use of these learning materials depends on the school regulation, whether the school is permitted their students to bring their own laptop or gadget to access the internet freely in the classroom or not.

To support the data from expert judgment and student's feedback, the researchers conducted an interview with the English teachers of TKR $A$ and TKR $B$. In the interview, the researchers asked about their opinions related to the content, presentation, language, and layout design of the learning materials. Overall, the teachers' responses implied that the learning materials are appropriate with the students' needs, and it had similarity with experts' responses and students' feedbacks. Since the English teachers suggested the cover picture, they supported the researchers if the pictures were related to a mechanic and workshop situation rather than changed to the student's picture. The reason is related to the background of the school is a vocational school with a specific study program.

Based on the results of expert judgment, student's feedback, and English teacher's feedback, it can be said that the learning materials are appropriate and ready to be implemented in the classroom, particularly for grade 11 students of Automotive Engineering study program of Vocational High School $A X$ on the first semester.

The product of this study was a set of supplementary reading and writing learning materials, which was based on discovery learning steps. These learning materials were intended for Grade 11 Students of the Automotive Engineering Study Program of Vocational High School AX, Indonesia. In supporting 21st-century skills in C-13, these learning materials implement collaborative skills, media literacy, and creativity. Discovery learning is described as the process of students being active in the class and identifying the key principles for themselves rather than simply accepting the teacher's explanation (Bruner in Lestari \& Priyana, 2019). The learning activities support learners to do collaborative learning. It was facilitated the way for the students to practice reading and writing. Hence, the development of the Discovery Learning activity was important to be conducted.

\section{CONCLUSION}

Based on the result of expert judgments, the learning materials are categorized "Very Good." The mean of field implementation was categorized as "Very Good." An interview was conducted with the English teachers to support the data from expert judgments and students' feedbacks. Based on the result of all, it can be said the reading and writing learning materials developed based on discovery learning were appropriate to be implemented. The learning materials had met the students' needs and the 2013 curriculum.

In developing learning materials, the researchers must consider several things, namely target need and learning needs. Researchers must know the basic science areas of expertise that will be developed in its learning material. If the researchers want to develop learning materials for automotive students, the researchers are asked to learn the basic foundation of automotive and the upcoming event in the automotive field. Related to the layout and presentation that should be made as attractive as possible, the choice of colors must be right, because colors can motivate students to learn, colored textbooks are more interesting than a black and white textbook.

The stakeholder must support the students in learning English by providing them an English textbook that is specifically designed for them. The stakeholders are asked to provide the students with a multi-colored textbook that can motivate the students in learning English. Because printing this book is quite expensive among students, it is expected that Vocational High School stakeholders can facilitate them regarding funding and ownership of the appropriate textbook, as well as other supporting facilities such as the internet and other scientific books in the Automotive field.

The product becomes a review for the policymaker in Vocational High School to further support Vocational High school students, especially in providing English textbooks that are appropriate with their interests. Considering there are many study programs in vocational high school that still need the same attention by the government, they need English textbooks that vary in number according to their study program. 


\section{REFERENCES}

Baturay, M. H., \& Akar, N. (2007). A new perspective for the integration of skills to reading. Tömer Language Journal, 136, 16-26.

Brown, H. D. (2001). Teaching by principles: An interactive approach to language pedagogy (2nd ed.). Pearson Education.

Brown, H. Douglas. (2004). Language assessment: Principal and classroom practice. Pearson Education.

Durmuş, A., \& Dağli, A. (2017). Integration of vocational schools to industry 4.0 by updating curriculum and programs. International Journal of Multidisciplinary Studies and Innovative Technologies, 1(1), 1-3. https://asosindex.com.tr/index.jsp?modul=articles-page\&journal-id $=968 \&$ article $-\mathrm{id}=52078$

Gijlers, H., \& de Jong, T. (2005). The relation between prior knowledge and students' collaborative discovery learning processes. Journal of Research in Science Teaching, 42(3), 264-282. https://doi.org/10.1002/tea.20056

Goyol, A., \& Sunday, G. (2020). Bridging the skills gap of graduates of technical colleges and the industries in Nigeria. International Journal of Vocational and Technical Education Research, 6(1), 1-9. https://www.eajournals.org/journals/international-journal-vocationaltechnical-education-research-ijvter/vol-6-issue-1-january-2020/bridging-the-skills-gap-ofgraduates-of-technical-colleges-and-the-industries-in-nigeria/

Guerid, F., \& Mami, N. A. (2017). Designing an ESP syllabus for finance and accounting staff. The Journal of Teaching English for Specific and Academic Purposes, 4(5), 771-780. https://doi. org/10.22190/JTESAP1704771G

Haq, A. H. B., Kurniawan, Y. I., Astuti, T., \& Kumaidi, K. (2019). Students' interest in vocational schools as the dimension of being in a wellbeing school model. International Journal of Vocational Education and Training Research, 5(2), 43-47. https://doi.org/10.11648/j.ijvetr. 20190502.11

Hui, Z. (2016). Teaching Automotive English to translator and interpreter students: Course design at Zhejiang University of Science and Technology. English for Specific Purposes, 23(8), 126.

Hutchinson, T., \& Waters, A. (1987). English for specific purpose. Cambridge University Press.

Jaleniauskiene, E., Leščinskij, R., \& Jucevičienè, P. (2019). Development of collaboration in the English for Specific Purposes courses: Opportunities and challenges. Journal of Teaching English for Specific and Academic Purposes, 7(3), 311-327. https://doi.org/10.22190/ JTESAP1903311J

Kadir, S., Nirwansyah, N., \& Backrul, B. A. (2016). Technical and Vocational Education and Training in Indonesia: Challenges and opportunities for the future. Lee Kuan Yew School of Public Policy, National University of Singapore.

Komarudin, K., Sutadji, E., \& Suhartadi, S. (2017). Contribution of teaching factory learning strategy implementation, mastery of basic knowledge, and self efficacy to the vocational competence and its impact to student work readiness in Malang Vocational Education of Motorcycle Engineering. Proceedings of the 1st International Conference on Vocational Education And Training (ICOVET 2017), 166-168. https://doi.org/10.2991/icovet-17.2017. 36

Law of Republic of Indonesia No. 20 of 2003 on National Education System, (2003).

Lestari, E., \& Priyana, J. (2019). Developing reading and writing learning materials for grade 11 students of Automotive Engineering Study Program of Vocational High School 1 Purworejo [Master thesis. Universitas Negeri Yogyakarta, Yogyakarta]. https://eprints.uny.ac.id/66969/ 
National Agency for Education Standard. (2016). Instrumen penilaian buku teks pembelajaran. National Agency for Education Standard.

Nunan, D. (2004). Task-based language teaching. Cambridge University Press.

Nurhajati, D. (2018). Project-based learning used to develop supplementary materials for writing skill. The Asian ESP Journal, 14(3), 6-11. https://www.elejournals.com/asian-esp-journal/ asian-esp-journal-volume-14-issue-3-august-2018/

Paltridge, B., \& Starfield, S. (Eds.). (2012). The handbook of English for Specific Purposes. John Wiley \& Sons. https://doi.org/10.1002/9781118339855

Regulation of Minister of National Education No. 22 of 2006 on Content Standard, (2006).

Richards, J. (2015). Keys issues in language teaching. Cambridge University Press.

Richards, J. C., \& Renandya, W. A. (2002). Methodology in language teaching: An anthology of current practice. Cambridge University Press.

Soeprijanto, S., Wahjono, T. D., Pakih, N., \& Muhadi, B. (2019). Model pembelajaran tematik integratif untuk sekolah kejuruan. Ministry of Education and Culture of Republic of Indonesia.

Sutman, F. X., Schmuckler, J. S., \& Woodfield, J. D. (2008). The science quest: Using inquiry/discovery to enhance student learning, grades 7-12. Jossey-Bass.

Yang, W. (2019). Developing tertiary level CLIL learners' intercultural awareness with a selfproduced coursebook integrating content and language. Journal of Teaching English for Specific and Academic Purposes, 7(3), 329-347. https://doi.org/10.22190/JTESAP1903329Y 